\title{
Effects of weaning and castration ages on growth performance, blood metabolites, and carcass characteristics in Hanwoo steers
}

\author{
Hwan Lim², Jun Sang Ahn ${ }^{1 \dagger}$, Min Ji Kim², Gi Hwal Son², Joong Kook Park , Jae Yoon Shim², Il Young Kim², \\ Ji Hyung Kim², Sung Myoun Cho ${ }^{2}$, Eung Gi Kwon ${ }^{1}$, Jong Suh Shin ${ }^{2}$ and Byung Ki Park ${ }^{3^{*}}$ (D)
}

\begin{abstract}
Background: Recently, as production costs have been increasing owing to rising feed prices worldwide, shortening the age of slaughter has been recognized as a way to increase farm income. In Korea, the raising period for Hanwoo steers is over 31 months with the delay of weaning and castration stated as one of the reasons for the increase in the raising period. Thus far, studies on age of weaning and castration have been conducted individually, and there have been no studies on the combined effects of weaning and castration ages on the growth performance and carcass characteristics in Hanwoo steers.

Methods: Weaning ages were calculated at 80 or 130 days of age, and castration ages were calculated at 90 days and 180 days of age. Calves were allocated to one of the four treatment groups: W80C90 (weaning at 80 days of age and castration at 90 days of age), W80C180, W130C90, and W130C180.

Results: For the entire experimental period, weaning and castration ages did not significantly affect growth performance of Hanwoo steers. In addition, weaning and castration ages did not affect the overall yield and quality traits of carcass in Hanwoo steers.

Conclusion: Weaning and castration ages had small effects on growth performance and carcass characteristics in Hanwoo steers. Therefore, the early weaning and castration ages are recommended to reduce the slaughter age without any negative effects on meat quality grade.
\end{abstract}

Keywords: Hanwoo, Weaning, Castration, Growth performance, Carcass characteristics

\section{Background}

The slaughter age can be changed depending on the age of weaning and castration, sex, nutrition, genetic traits, feed costs, and price of carcasses [20, 27]. Recently, as production costs have been increasing owing to rising feed prices worldwide, shortening the age of slaughter has been recognized as a way to increase farm income. Therefore, it is necessary to look for ways to shorten the age of slaughter while maintaining growth performance and meat quality.

\footnotetext{
* Correspondence: animalpark@hanmail.net

${ }^{\dagger}$ Hwan Lim and Jun Sang Ahn contributed equally to this work.

${ }^{3}$ Nonghyup Feed Co., LTD, Seoul 05398, South Korea

Full list of author information is available at the end of the article
}

In the Korea feeding standard [23], 90 days of age is suggested as a suitable weaning age; however, there are still many farms that do not wean until after 120 days of age. In addition, the study of the optimal weaning age for Hanwoo calves has been conducted mainly on the body weight gain only until the growing period [23].

The optimal age of castration for Hanwoo calves is recommended before 8 months of age; however, many farms are conducting castration from 4 to 14 months of age. In Korea, the raising period for Hanwoo steers is over 31 months $[4,16,28]$ with the delay of weaning and castration stated as one of the reasons for the increase in the raising period. Thus far, studies on age of weaning and castration have been conducted individually, and

(c) The Author(s). 2018 Open Access This article is distributed under the terms of the Creative Commons Attribution 4.0 International License (http://creativecommons.org/licenses/by/4.0/), which permits unrestricted use, distribution, and reproduction in any medium, provided you give appropriate credit to the original author(s) and the source, provide a link to the Creative Commons license, and indicate if changes were made. The Creative Commons Public Domain Dedication waiver (http://creativecommons.org/publicdomain/zero/1.0/) applies to the data made available in this article, unless otherwise stated. 
there have been no studies on the combined effects of weaning and castration ages on the growth performance and carcass grade in Hanwoo steers.

It is reported that shortening of the weaning age is advantageous for reproductive efficiency of calving cows $[17,22]$, growth performance of calves [3, 11, 25], improving carcass quality $[19,21]$, and profitability of steers [32].

Even if castration is recommended for producing high-quality meat [35], the optimal age of castration has not been clearly defined. In general, the delay of castration is favorable for average daily gain (ADG) [10, 34], feed efficiency $[2,6]$, and carcass weight $[26,30]$; however, it has been reported to be disadvantageous for meat quality characteristics such as marbling $[5,9,13]$ and texture $[26,30]$. To prevent deterioration of carcass quality (meat quality grade) due to castration delay, an additional fattening period is required. Thus, early castration is advantageous if the aim is to shorten the slaughter age while maintaining the marbling score and meat quality grade.

The present study was undertaken to investigate the effects of weaning and castration ages on the growth performance, blood metabolites, and carcass characteristics of Hanwoo steers. Additionally, the study was conducted to identify the optimal weaning and castration ages that can maintain meat quality while shortening the slaughter age by responding to the price decrease of high class meat or the increase of international grain prices.

\section{Methods}

\section{Experimental period and animals}

The present study was conducted using different weaning and castration ages over almost 3 years, from March 2015 to November 2017. Forty-eight Hanwoo calves were delivered sequentially from March to April 2015 for approximately 35 days at a farm in Anseong, Gyeonggi-do.

\section{Treatments and management}

Weaning ages (W) were calculated at 80 or 130 days of age, and castration ages (C) were calculated at 90 days and 180 days of age. In the present study, the early weaning and castration ages were determined to be 80 and 90 days of age, respectively, because weaning and castration at many Hanwoo farms are conventionally practiced after 120 (4 months of age) and 180 days (6 months of age), respectively. Calves were allocated to one of the four treatment groups: W80C90 (weaning at 80 days of age and castration at 90 days of age), W80C180 (weaning at 80 days of age and castration at 180 days of age), W130C90 (weaning at 130 days of age and castration at 90 days of age), and W130C180 (weaning at 130 days of age and castration at 180 days of age).
Weaning and castration ages were determined by calculating the ordered average birth date of 12 out of 48 bull calves born on March 1, 2015. The mean births of W80C90, W80C180, W130C90, and W130C180 were March 9 ( \pm 2.9 days), March 20 ( \pm 2.8 days), March 26 ( \pm 1.4 days), and April 5 ( \pm 3.8 days), respectively. The castrations were performed under surgical procedure. Calves of W130C90 were treated and stabilized in an independent space for approximately one day after castration, and then placed in pens with their mother.

Six calves were allocated per pen $(5 \times 10 \mathrm{~m})$ with sawdust to a thickness of approximately $20 \mathrm{~cm}$. Concentrate was fed three times daily $(08: 30,13: 00$, and 17:00) using an automatic feeding system. Concentrate was restrictively fed at $1.7 \%$ of body weight (as-fed basis) from the growing to early fattening periods and was restrictively fed at $1.3 \%$ of body weight for the late fattening period. Rice straw (dry matter 90.18\%, crude protein 3.65\%, ether extract $1.02 \%$, crude fiber $34.19 \%$, neutral detergent fiber $70.21 \%$, acid detergent fiber $38.13 \%$, crude ash $10.58 \%$, Ca $0.09 \%$, and P $0.05 \%$ ) was fed in fixed amounts based on months of age. Water could be accessed freely. The formula percentages and nutrient contents of the experimental diets are presented in Table 1.

\section{Measurements and analysis}

Average daily gain (ADG) was calculated by measuring body weight at 10 am every 2 months. Feed intake was measured weekly and the amount of feed intake was determined by measuring the orts present before morning feeding. The feed conversion ratio (FCR) was calculated using dry matter intake (DMI) and ADG.

Blood samples were taken at 2 monthly intervals from the jugular vein of the experimental animals. A $3 \mathrm{ml}$ sample of blood for analysis of blood chemical values was collected using an 18-gauge needle and a vacuum blood vessel (Vacutainer; Becton- Dickinson, NJ) coated with anticoagulant. The collected blood was stored in an ice box and transferred to the laboratory within $6 \mathrm{~h}$. The blood was centrifuged at $3000 \times g$ for $10 \mathrm{~min}$ to separate the serum and was analyzed using an automatic blood analyzer (Hitachi 7020, Hitachi Ltd., Tokyo, Japan). Factors measured included glucose, total cholesterol, albumin, total protein, triglyceride, total bilirubin, blood urea nitrogen (BUN), gamma-glutamyl transpeptidase (GGT), glutamic oxaloacetic transaminase (GOT), glutamic-pyruvic transaminase (GPT), non-esterified fatty acid (NEFA), creatinine, calcium $(\mathrm{Ca})$, phosphorus $(\mathrm{P})$, and magnesium $(\mathrm{Mg})$. Chemical compositions of the experimental diets were analyzed based on the method described by AOAC [1] and Van Soest [33].

At the end of the experimental period, all steers were slaughtered at the local slaughterhouse to assess carcass 
Table 1 Formula and chemical composition of experimental diets (as-fed basis)

\begin{tabular}{|c|c|c|c|c|}
\hline Item & Calf starter & Growing & Early fattening & Late fattening \\
\hline & \multicolumn{4}{|l|}{ Formula (\%) } \\
\hline Corn grain & 5.00 & 27.0 & 35.6 & 37.0 \\
\hline Wheat grain & 9.90 & 8.0 & 9.0 & 17.6 \\
\hline Milk replacer & 10.15 & - & - & - \\
\hline Cane molasses & - & 4.5 & 4.0 & 5.3 \\
\hline Tapioca residue & - & 2.9 & 4.0 & 5.3 \\
\hline Wheat flour & - & 1.0 & 1.0 & 1.0 \\
\hline Rapeseed meal & - & 6.0 & 0.8 & - \\
\hline Whey powder & 10.00 & - & - & - \\
\hline Soybean hull & 10.00 & - & - & - \\
\hline Wheat bran & 14.00 & 7.0 & 5.0 & 5.0 \\
\hline Corn gluten feed & 10.00 & 13.0 & 14.0 & 15.0 \\
\hline Isolated soy protein & 5.50 & - & - & - \\
\hline Distillers grain & - & 8.1 & - & - \\
\hline Coconut meal & - & 6.0 & 5.0 & 1.8 \\
\hline Palm kernel meal & - & 12.0 & 10.0 & 6.0 \\
\hline Banana meal & 10.00 & - & - & - \\
\hline Beet pulp & 8.00 & - & - & - \\
\hline Soybean oil & 3.00 & 0.1 & 0.1 & 0.1 \\
\hline Limestone (1 mm) & 1.85 & 2.4 & 1.7 & 1.5 \\
\hline Salt dehydrate & 0.50 & 0.5 & 0.5 & 0.5 \\
\hline DCP & 0.40 & - & - & - \\
\hline \multirow[t]{2}{*}{ Calf mix (additive) } & 1.70 & - & - & - \\
\hline & \multicolumn{4}{|c|}{ Chemical composition (\%) } \\
\hline Dry matter & 89.80 & 88.67 & 88.50 & 87.71 \\
\hline Crude protein & 24.30 & 14.10 & 12.16 & 12.00 \\
\hline Ether extract & 7.56 & 3.69 & 4.33 & 3.47 \\
\hline Crude fiber & 4.72 & 7.30 & 6.82 & 6.71 \\
\hline $\mathrm{NDF}^{1}$ & 27.13 & 26.51 & 24.79 & 23.76 \\
\hline $\mathrm{Ca}$ & 1.30 & 1.13 & 0.80 & 0.85 \\
\hline$P$ & 0.69 & 0.45 & 0.39 & 0.35 \\
\hline Crude ash & 8.39 & 7.89 & 5.79 & 5.30 \\
\hline TDN & 84.50 & 70.41 & 72.92 & 73.32 \\
\hline
\end{tabular}

$D C P$ dicalcium phosphate, NDF neutral detergent fiber, $T D N$ total digestible nutrients

yield and quality grades. Carcass traits were determined at the 13th rib section from the left side of each carcass and graded by meat graders using the criteria described by the Korean carcass grading system [14]. Meat quality traits were measured for marbling score, meat color, fat color, texture, and maturity, and yield traits were measured for carcass weight, back fat thickness, and rib eye area. Carcass yield index (YI) was calculated based on the following equation: $\mathrm{YI}=[68.184-(0.625 \times$ back fat thickness, $\mathrm{mm})+\left(0.130 \times\right.$ rib eye area, $\left.\mathrm{cm}^{2}\right)-(0.024 \times$ carcass weight, $\mathrm{kg})]$.
From this equation, scores over 67.50 were rated as $\mathrm{A}$ (best), scores of 62.00-67.50 were rated as B, and scores less than 62.00 were rated as $C$ (worst). The meat quality grades were $1^{++}$grade (best) for 8 and $9,1^{+}$grade for 6 and 7, 1 grade for 4 and 5, 2 grade for 2 and 3, and 3 grade (worst) for 1 . For the statistical analysis of the yield grade, 3 points were given for yield grade A, 2 points for $\mathrm{B}$ grade, and 1 point for $\mathrm{C}$ grade. In the case of the quality grade, 5 points were given for quality grade $1^{++}, 4$ points for $1^{+}$grade, 3 points for 1 grade, 2 points for 2 grade, and 1 point for 3 grade. 


\section{Statistical analysis}

In the present study, to estimate the environmental effects on body weight, ADG, and blood metabolite concentration based on weaning and castration ages, the following linear model was used for least squares analysis: $\quad y_{i j k l}=\mu+T_{R T}+\beta_{1} X_{1 i j}+\beta_{2} X_{2 i k}+e_{i j k l}$, where, $\mu=$ overall average, $\mathrm{TRT}_{\mathrm{i}}=$ effect of treatment (1-4), $\mathrm{X}_{1}, \mathrm{X}_{2}=$ covariation of castration age and measurement month, $\beta_{1}, \beta_{2}=$ regression coefficient, and $e_{\mathrm{ijk}}=$ random error effect.

The least squares method was performed to estimate environmental effects on body weight, ADG, feed intake, FCR, and concentration of blood metabolites by combining the treatment groups (same weaning and castration ages): $y_{i j}=\mu+\mathrm{TRT}_{\mathrm{i}}+\mathrm{e}_{\mathrm{ij}}$, where, $\mu=$ overall average, $\mathrm{TRT}_{\mathrm{i}}=$ effect of treatment (1-4), and $\mathrm{e}_{\mathrm{ij}}=$ random error effect.

The linear model was analyzed using SAS 9.1 [29] software package and the variance analysis was performed using Type III squared fit for unbalanced data among the four squares presented in the SAS/generalized linear model analysis. The statistical significance differences for the treatments between the least squares averages were tested with the following null hypothesis at significance level of $5 \%$ : Ho: $\operatorname{LSM}(i)=\operatorname{LSM}(j)$, where, $\operatorname{LSM}(i(j))$ is the least squares average of the $I(j)$ the effects $(I \neq j)$.

All results of the present study were analyzed by $t$-tests using the least significant difference procedure of the SAS package program (release. 9.1.3 version, 2005). The statistically significant differences of feed intake, body weight, and concentration of blood metabolites between groups were analyzed following the generalized linear model: $\mathrm{Y}_{\mathrm{ij}}=\mu+\mathrm{TRT}_{\mathrm{i}}+\mathrm{e}_{\mathrm{ij}}$, where, $\mu=$ overall average, $\mathrm{TRT}_{\mathrm{i}}=$ effect of treatment $(1-4)$, and $\mathrm{e}_{\mathrm{ij}}=$ random error effect.

\section{Results and discussion Growth performance}

For the growing period, ADG was lower in W130C180 than that of the other treatment groups (Table 2); however, there was no statistically significant difference. FCR was lower in W80C180 than that of W130C180 $(P<0.05)$; however, results were similar between the other treatment groups. For the early and late fattening periods, ADGs were higher in W80C90 than that of the other treatment groups; however, there was no statistically significant difference. FCRs were lower in W80C90 than that of the other treatment groups. For the entire experimental period, there were no effects of the weaning and castration ages on ADG and FCR of Hanwoo steers. There were no differences in concentrate, rice straw, and dry matter intakes between treatment groups because concentration and rice straw were restricted by the weight of steers over the entire experimental period.
For the growing period, ADG was lower in W130 than that of W80 (Table 3); however, there was no statistically significant difference. There were no effects of weaning age on ADG, feed intake, and FCR over the entire experimental period.

For the growing period, there were no differences in ADG and FCR based on the castration age (Table 4). Final body weight was $5.4 \mathrm{~kg}$ higher in $\mathrm{C} 180$ than that in C90; however, there was no statistically significant difference. There were no effects of castration age on ADG, feed intake, and FCR over the entire experimental period.

In the present study, there were no overall effects of weaning and castration ages on ADG, feed intake, and FCR of Hanwoo steers; however, the final body weight was considered to be slightly advantageous in the customary weaning and castration ages than that in the early weaning and castration ages. Previous studies $[24,25]$ reported that the early weaned calves had higher ADG. However, ADG tended to be slightly higher for the growing period owing to the early weaning in the present study, yet they were similar between the other treatment groups over the entire experimental period. These results are caused by differences in calf management methods, experimental periods (weaning to growing vs. weaning to late fattening), and feeding method of concentrate (ad libitum or restricted feeding).

Kwon et al. [15] reported that there was no effect of the weaning ages (90 and 120 days) on concentrates, rice straw, dry matter, crude protein, and TDN intakes, which is in agreeance with our results. In the present study, there was no difference in feed intake until 3 months of age, as the amount of milk suckling was limited to two times per day from 1 month after birth. The results of no significant difference in feed intake were due to restricted feeding of concentrates $1.7 \%$ of $\mathrm{BW}$ for growing and early fattening periods and $1.3 \%$ of BW for late fattening period) and fixed feeding of rice straw by months of age. In the present study, the purpose of limited milk suckling was to increase concentrate and hay intake considering the rapid increase in energy demand of calves from 3 weeks of age and the rapid decrease in milk yield of mother cows [11]. Therefore, the ADG of calves was not lower than that of the early weaning age if the amount of milk suckling is restricted from 1 month after birth. This result would be useful to share with farmers for incorporation into their management systems.

In the present study, we did not investigate return to estrus, services per conception, and calving interval based on the weaning age. However, it is desirable to shorten the weaning age as much as possible, considering shortening of return to estrous [31] and improvement of reproductive efficiency $[8,17,24]$. 
Table 2 Effects of weaning and castration ages on growth performance of Hanwoo steers

\begin{tabular}{|c|c|c|c|c|c|}
\hline \multirow[t]{2}{*}{ Item } & \multicolumn{4}{|l|}{ Treatment $^{c}$} & \multirow[t]{2}{*}{$P$-value } \\
\hline & W80C90 & W80C180 & W130C90 & W130C180 & \\
\hline & \multicolumn{4}{|c|}{ Growing period (3-12 months of age) } & \\
\hline Initial body weight (kg) & $112.7 \pm 12.3$ & $114.9 \pm 13.8$ & $118.7 \pm 10.8$ & $110.7 \pm 13.7$ & 0.062 \\
\hline Final body weight (kg) & $314.6 \pm 31.3$ & $317.5 \pm 29.2$ & $320.2 \pm 24.0$ & $299.0 \pm 23.8$ & 0.277 \\
\hline Average daily gain (kg) & $0.74 \pm 0.08$ & $0.75 \pm 0.08$ & $0.74 \pm 0.07$ & $0.70 \pm 0.06$ & 0.362 \\
\hline Concentrate (DM, kg) & $3.58 \pm 0.58$ & $3.58 \pm 0.58$ & $3.58 \pm 0.58$ & $3.58 \pm 0.58$ & - \\
\hline Rice straw (DM, kg) & $1.78 \pm 0.25$ & $1.78 \pm 0.25$ & $1.78 \pm 0.25$ & $1.78 \pm 0.25$ & - \\
\hline Dry matter intake (kg) & $5.36 \pm 0.57$ & $5.36 \pm 0.57$ & $5.36 \pm 0.57$ & $5.36 \pm 0.57$ & - \\
\hline \multirow[t]{2}{*}{ Feed conversion ratio } & $7.24^{\mathrm{ab}} \pm 0.60$ & $6.96^{\mathrm{b}} \pm 0.65$ & $7.24^{\mathrm{ab}} \pm 0.51$ & $8.68^{\mathrm{a}} \pm 0.53$ & 0.011 \\
\hline & \multicolumn{4}{|c|}{ Early fattening period (13-22 months of age) } & \\
\hline Initial body weight (kg) & $314.6 \pm 31.3$ & $317.5 \pm 29.2$ & $320.2 \pm 24.0$ & $299.0 \pm 23.8$ & 0.277 \\
\hline Final body weight (kg) & $569.5 \pm 40.5$ & $584.7 \pm 56.2$ & $583.8 \pm 57.8$ & $570.7 \pm 48.9$ & 0.828 \\
\hline Average daily gain $(\mathrm{kg})$ & $0.84 \pm 0.05$ & $0.88 \pm 0.11$ & $0.87 \pm 0.12$ & $0.90 \pm 0.13$ & 0.500 \\
\hline Concentrate (DM, kg) & $5.82 \pm 1.11$ & $5.82 \pm 1.11$ & $5.82 \pm 1.11$ & $5.82 \pm 1.11$ & - \\
\hline Rice straw (DM, kg) & $2.39 \pm 0.21$ & $2.39 \pm 0.21$ & $2.39 \pm 0.21$ & $2.39 \pm 0.21$ & - \\
\hline Dry matter intake (kg) & $8.21 \pm 0.45$ & $8.21 \pm 0.45$ & $8.21 \pm 0.45$ & $8.21 \pm 0.45$ & - \\
\hline \multirow[t]{2}{*}{ Feed conversion ratio } & $10.06 \pm 0.77$ & $9.70 \pm 1.41$ & $9.71 \pm 1.31$ & $9.41 \pm 1.59$ & 0.714 \\
\hline & \multicolumn{4}{|c|}{ Late fattening period (23-31 months of age) } & \\
\hline Initial body weight (kg) & $569.5 \pm 40.5$ & $584.7 \pm 56.2$ & $583.8 \pm 57.8$ & $570.7 \pm 48.9$ & 0.838 \\
\hline Final body weight (kg) & $756.5 \pm 60.1$ & $783.0 \pm 79.3$ & $781.8 \pm 75.6$ & $766.1 \pm 72.9$ & 0.793 \\
\hline Average daily gain (kg) & $0.65 \pm 0.09$ & $0.69 \pm 0.12$ & $0.69 \pm 0.08$ & $0.68 \pm 0.17$ & 0.868 \\
\hline Concentrate (DM, kg) & $7.97 \pm 0.81$ & $8.13 \pm 0.64$ & $8.13 \pm 0.64$ & $8.13 \pm 0.64$ & - \\
\hline Rice straw (DM, kg) & $0.96 \pm 0.34$ & $0.96 \pm 0.34$ & $0.96 \pm 0.34$ & $0.96 \pm 0.34$ & - \\
\hline Dry matter intake (kg) & $8.93 \pm 0.83$ & $9.09 \pm 0.64$ & $9.10 \pm 0.64$ & $9.10 \pm 0.64$ & - \\
\hline \multirow[t]{2}{*}{ Feed conversion ratio } & $13.77 \pm 3.93$ & $11.98 \pm 2.03$ & $11.87 \pm 1.66$ & $12.10 \pm 2.39$ & 0.642 \\
\hline & \multicolumn{4}{|c|}{ Entire period (3-31 months of age) } & \\
\hline Initial body weight (kg) & $112.7 \pm 12.3$ & $114.9 \pm 13.8$ & $118.7 \pm 10.8$ & $110.7 \pm 13.7$ & 0.062 \\
\hline Final body weight (kg) & $756.5 \pm 60.1$ & $783.0 \pm 79.3$ & $781.8 \pm 75.6$ & $766.1 \pm 72.9$ & 0.793 \\
\hline Average daily gain $(\mathrm{kg})$ & $0.75 \pm 0.06$ & $0.78 \pm 0.07$ & $0.77 \pm 0.05$ & $0.77 \pm 0.08$ & 0.739 \\
\hline Concentrate (DM, kg) & $5.72 \pm 2.33$ & $5.78 \pm 2.37$ & $5.75 \pm 2.43$ & $5.75 \pm 2.43$ & - \\
\hline Rice straw (DM, kg) & $1.73 \pm 0.65$ & $1.73 \pm 0.65$ & $1.69 \pm 0.67$ & $1.69 \pm 0.67$ & - \\
\hline Dry matter intake (kg) & $7.45 \pm 2.17$ & $7.50 \pm 2.19$ & $7.45 \pm 2.33$ & $7.45 \pm 2.33$ & - \\
\hline Feed conversion ratio & $10.2 \pm 4.09$ & $9.35 \pm 3.05$ & $9.26 \pm 3.11$ & $9.30 \pm 3.31$ & 0.879 \\
\hline
\end{tabular}

Means \pm standard deviation

${ }^{\mathrm{a}, \mathrm{b}}$ Means with different superscripts within the same row are significantly different $(P<0.05)$

'W80C90: weaning at 80 days of age and castration at 90 days of age; W80C180: weaning at 80 days of age and castration at 180 days of age; W130C90: weaning at 130 days of age and castration at 90 days of age; W130C180: weaning at 130 days of age and castration at 180 days of age

In the experimental design process of the present study, the early castration was predicted to be disadvantageous to ADG and FCR compared to the customary castration age. However, from the results, there was no effect of castration age on ADG and FCR, which appears to be related to castration age and feeding methods. Regardless of the treatment group, there was no significant difference in stress between the treatment groups as all calves were castrated before puberty. In addition, although there was a slight difference in ADG and FCR over the growing period, there was no difference in ADG and FCR based on the castration age over the entire experimental period because there was similar feed intake owing to the restricted feeding of concentrate.

In general, delayed castration is known as being advantageous to $\operatorname{ADG}[10,34]$ and feed efficiency $[2,6]$. 
Table 3 Effects of weaning age on growth performance of Hanwoo steers

\begin{tabular}{|c|c|c|c|c|}
\hline \multirow[t]{2}{*}{ Item } & \multicolumn{2}{|l|}{ Weaning age $\mathrm{a}^{\mathrm{a}}$} & \multirow[t]{2}{*}{ SE } & \multirow[t]{2}{*}{$\operatorname{Pr}>|t|$} \\
\hline & W80 & W130 & & \\
\hline & \multicolumn{4}{|c|}{ Growing period (3-12 months of age) } \\
\hline Initial body weight (kg) & $110.3 \pm 13.3$ & $111.5 \pm 14.3$ & 3.816 & 0.758 \\
\hline Final body weight (kg) & $316.1 \pm 30.3$ & $309.6 \pm 26.1$ & 8.807 & 0.472 \\
\hline Average daily gain $(\mathrm{kg})$ & $0.75 \pm 0.08$ & $0.72 \pm 0.06$ & 0.023 & 0.237 \\
\hline Concentrate (DM, kg) & $3.58 \pm 0.58$ & $3.58 \pm 0.58$ & - & - \\
\hline Rice straw (DM, kg) & $1.78 \pm 0.25$ & $1.78 \pm 0.25$ & - & - \\
\hline Dry matter intake (kg) & $5.36 \pm 0.57$ & $5.36 \pm 0.57$ & - & - \\
\hline \multirow[t]{2}{*}{ Feed conversion ratio } & $7.15 \pm 0.63$ & $7.44 \pm 0.53$ & 0.180 & 0.269 \\
\hline & \multicolumn{4}{|c|}{ Early fattening period (13-22 months of age) } \\
\hline Initial body weight (kg) & $316.1 \pm 30.3$ & $309.6 \pm 26.1$ & 8.807 & 0.472 \\
\hline Final body weight (kg) & $577.1 \pm 49.6$ & $577.3 \pm 53.9$ & 14.282 & 0.857 \\
\hline Average daily gain (kg) & $0.86 \pm 0.09$ & $0.89 \pm 0.13$ & 0.032 & 0.248 \\
\hline Concentrate (DM, kg) & $5.82 \pm 1.11$ & $5.82 \pm 1.11$ & - & - \\
\hline Rice straw (DM, kg) & $2.39 \pm 0.21$ & $2.39 \pm 0.21$ & - & - \\
\hline Dry matter intake (kg) & $8.21 \pm 0.45$ & $8.21 \pm 0.45$ & - & - \\
\hline \multirow[t]{2}{*}{ Feed conversion ratio } & $9.88 \pm 1.15$ & $9.56 \pm 1.47$ & 0.355 & 0.378 \\
\hline & \multicolumn{4}{|c|}{ Late fattening period (23-31 months of age) } \\
\hline Initial body weight $(\mathrm{kg})$ & $577.10 \pm 50.63$ & $577.27 \pm 55.07$ & 52.900 & 0.991 \\
\hline Final body weight (kg) & $769.77 \pm 73.13$ & $773.94 \pm 76.28$ & 74.721 & 0.848 \\
\hline Average daily gain $(\mathrm{kg})$ & $0.67 \pm 0.12$ & $0.69 \pm 0.14$ & 0.128 & 0.707 \\
\hline Concentrate (DM, kg) & $8.05 \pm 0.71$ & $8.13 \pm 0.62$ & - & - \\
\hline Rice straw (DM, kg) & $0.96 \pm 0.33$ & $0.96 \pm 0.33$ & - & - \\
\hline Dry matter intake (kg) & $9.01 \pm 0.73$ & $9.10 \pm 0.62$ & - & - \\
\hline \multirow[t]{2}{*}{ Feed conversion ratio } & $12.87 \pm 3.09$ & $11.99 \pm 1.95$ & 2.586 & 0.454 \\
\hline & \multicolumn{4}{|c|}{ Entire period (3-31 months of age) } \\
\hline Initial body weight (kg) & $110.3 \pm 13.3$ & $111.5 \pm 14.3$ & 14.100 & 0.772 \\
\hline Final body weight (kg) & $769.8 \pm 71.6$ & $773.9 \pm 74.7$ & 74.721 & 0.848 \\
\hline Average daily gain $(\mathrm{kg})$ & $0.77 \pm 0.07$ & $0.77 \pm 0.08$ & 0.079 & 0.881 \\
\hline Concentrate (DM, kg) & $5.75 \pm 2.33$ & $5.75 \pm 2.41$ & - & - \\
\hline Rice straw (DM, kg) & $1.73 \pm 0.65$ & $1.69 \pm 0.67$ & - & - \\
\hline Dry matter intake (kg) & $7.47 \pm 2.17$ & $7.45 \pm 2.31$ & - & - \\
\hline Feed conversion ratio & $9.77 \pm 3.56$ & $9.28 \pm 3.14$ & 3.358 & 0.601 \\
\hline
\end{tabular}

Means \pm standard deviation

aW80: weaning at 80 days of age at weaning; W130: weaning at 130 days of age

However, Worrell et al. [35] reported that early castration before puberty did not reduce ADG. This finding supports the results of the present study. In addition, previous studies $[5,7]$ reported similar results as the present study that there was no difference in ADG in relation to the castration age. When castration is delayed, increased stress $[12,13]$ occurs and the extension of the fattening period $[5,13]$ is inevitable to produce the same meat quality grade. Therefore, early castration is advantageous to shorten the age of slaughter taking into consideration the meat quality grade.

\section{Blood metabolites}

There were no effects of weaning and castration ages on concentrations of albumin, BUN, total protein, glucose, creatinine, cholesterol, total glyceride, NEFA, Ca, P, GOT, GPT, and GGT of Hanwoo steers (Table 5).

There were no effects of weaning and castration ages on concentrations of blood metabolites, which was due to no difference in feed intake between the treatment groups in the present study (Tables 2, 3, and 4). In the present study, there was no difference in concentration of blood metabolites owing to similar nutrient supply 
Table 4 Effects of castration age on growth performance of Hanwoo steers

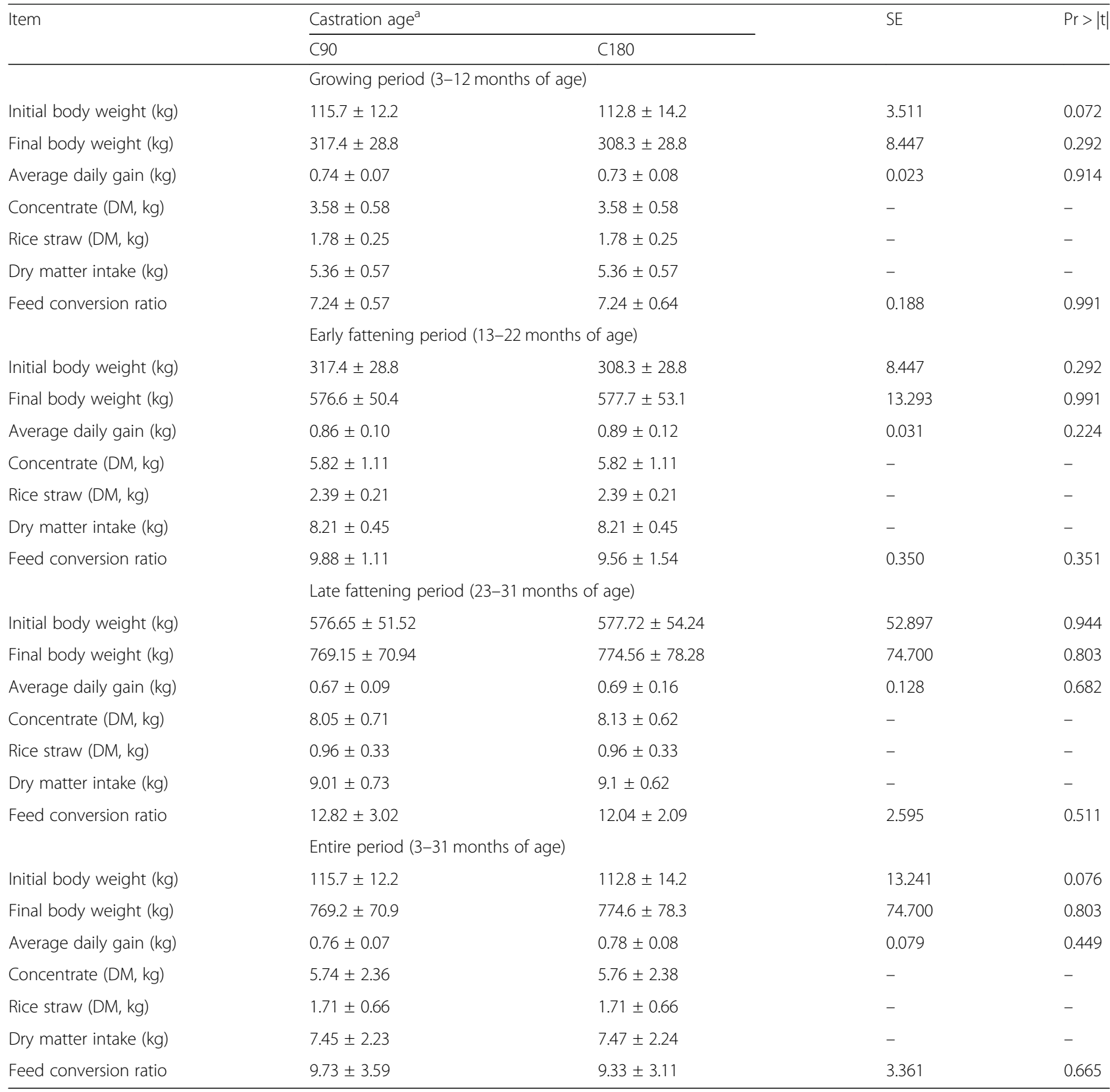

Means \pm standard deviation

${ }^{\text {ac }}$ 90: castration at 90 days of age; C180: castration at 180 days of age

and utilization efficiency between the treatment groups because of castration before puberty, limited feeding of concentrates, and fixed feeding of rice straw.

\section{Carcass characteristics}

The carcass weight tended to be lower in W80C90 than that of the other treatment groups (Table 6). The rib eye area was wider in W130C90 than that of the other treatment groups; however, there was no statistically significant difference. There were only small effects of weaning and castration ages on the overall yield traits (carcass weight, back fat thickness, rib eye area, yield index, and yield grade score) of Hanwoo steers. The marbling and meat quality scores were higher in W130C90 than that of the other treatment groups; however, there was no statistically significant difference. There were no effects of weaning and castration ages on meat color, fat color, and texture.

Although there was no statistically significant difference, carcass weight ( 456.52 vs. $466.78 \mathrm{~kg}$ ), rib eye area $\left(93.81\right.$ vs. $\left.99.13 \mathrm{~cm}^{2}\right)$, and meat quality grade score $(1.86$ vs. 2.04) was higher in W130 than that in W80, 
Table 5 Effects of weaning and castration ages on metabolites of Hanwoo steers

\begin{tabular}{|c|c|c|c|c|c|c|}
\hline \multirow[t]{2}{*}{ Item } & \multicolumn{4}{|c|}{ Treatment $^{\mathrm{a}}$} & \multirow[t]{2}{*}{ SE } & \multirow[t]{2}{*}{$P$-value } \\
\hline & $\overline{\text { W80C90 }}$ & W80C180 & W130C90 & W130C180 & & \\
\hline & \multicolumn{4}{|c|}{ Growing period (3-12 months of age) } & & \\
\hline Albumin (g/dl) & 3.43 & 3.55 & 3.63 & 3.53 & 0.142 & 0.225 \\
\hline BUN (mg/dl) & 13.23 & 12.98 & 13.26 & 12.46 & 1.248 & 0.353 \\
\hline Total protein $(\mathrm{g} / \mathrm{dl})$ & 6.24 & 6.54 & 6.69 & 6.45 & 0.337 & 0.321 \\
\hline Glucose (mg/dl) & 62.83 & 62.83 & 65.58 & 68.75 & 11.255 & 0.311 \\
\hline Creatinine $(\mathrm{mg} / \mathrm{dl})$ & 0.98 & 1.00 & 1.07 & 1.05 & 0.124 & 0.235 \\
\hline Cholesterol (mg/dl) & 126.08 & 113.83 & 128.67 & 115.58 & 24.226 & 0.105 \\
\hline Total glyceride (mg/dl) & 24.52 & 24.33 & 24.42 & 22.65 & 2.561 & 0.325 \\
\hline $\mathrm{NEFA}(\mu \mathrm{Eq} / \mathrm{L})$ & 107.92 & 149.42 & 141.92 & 135.83 & 27.331 & 0.289 \\
\hline Calcium (mg/dl) & 9.59 & 9.66 & 9.23 & 9.14 & 0.318 & 0.335 \\
\hline Phosphorus (mg/dl) & 8.60 & 8.77 & 8.73 & 8.57 & 0.614 & 0.312 \\
\hline GOT (IU/L) & 68.50 & 62.92 & 60.42 & 62.33 & 7.203 & 0.114 \\
\hline GPT (IU/L) & 25.77 & 24.56 & 22.82 & 24.15 & 5.365 & 0.235 \\
\hline \multirow[t]{2}{*}{ GGT (mg/dl) } & 22.67 & 19.08 & 19.75 & 19.92 & 3.217 & 0.164 \\
\hline & \multicolumn{4}{|c|}{ Early fattening period (13-22 months of age) } & & \\
\hline Albumin $(\mathrm{g} / \mathrm{dl})$ & 3.98 & 4.38 & 4.21 & 3.98 & 0.149 & 0.055 \\
\hline BUN (mg/dl) & 12.70 & 11.45 & 13.00 & 10.93 & 0.388 & 0.160 \\
\hline Total protein (g/dl) & 8.21 & 8.50 & 8.42 & 8.27 & 0.222 & 0.748 \\
\hline Glucose (mg/dl) & 60.13 & 63.29 & 59.92 & 66.22 & 2.120 & 0.386 \\
\hline Creatinine (mg/dl) & 1.16 & 1.36 & 1.33 & 1.27 & 0.073 & 0.268 \\
\hline Cholesterol (mg/dl) & 171.58 & 132.42 & 147.85 & 157.63 & 12.299 & 0.109 \\
\hline Total glyceride $(\mathrm{mg} / \mathrm{dl})$ & 17.08 & 18.75 & 16.50 & 19.24 & 1.358 & 0.506 \\
\hline NEFA $(\mu \mathrm{Eq} / \mathrm{L})$ & 244.42 & 291.25 & 331.46 & 319.39 & 19.539 & 0.162 \\
\hline Calcium (mg/dl) & 9.30 & 9.50 & 9.30 & 8.46 & 0.182 & 0.179 \\
\hline Phosphorus (mg/dl) & 7.87 & 7.52 & 7.90 & 8.28 & 0.950 & 0.404 \\
\hline GOT (IU/L) & 63.13 & 56.29 & 70.00 & 52.67 & 5.813 & 0.337 \\
\hline GPT (IU/L) & 27.55 & 26.92 & 28.10 & 34.42 & 3.526 & 0.876 \\
\hline \multirow[t]{2}{*}{ GGT (mg/dl) } & 22.25 & 19.79 & 27.39 & 24.84 & 2.407 & 0.135 \\
\hline & \multicolumn{4}{|c|}{ Late fattening period (23-31 months of age) } & & \\
\hline Albumin $(\mathrm{g} / \mathrm{dl})$ & 4.26 & 4.45 & 4.40 & 4.36 & 0.242 & 0.343 \\
\hline BUN (mg/dl) & 16.74 & 17.40 & 17.65 & 16.76 & 3.053 & 0.966 \\
\hline Total protein (g/dl) & 8.94 & 9.00 & 8.98 & 9.01 & 0.501 & 0.783 \\
\hline Glucose (mg/dl) & 92.50 & 92.88 & 95.83 & 104.38 & 6.462 & 0.106 \\
\hline Creatinine (mg/dl) & 1.56 & 1.54 & 1.53 & 1.54 & 0.176 & 0.843 \\
\hline Cholesterol (mg/dl) & 179.88 & 164.38 & 178.17 & 189.88 & 32.915 & 0.869 \\
\hline Total glyceride (mg/dl) & 39.63 & 34.00 & 47.50 & 38.00 & 10.654 & 0.086 \\
\hline NEFA $(\mu E q / L)$ & 132.50 & 102.38 & 127.83 & 114.25 & 62.398 & 0.323 \\
\hline Calcium (mg/dl) & 10.08 & 8.91 & 9.85 & 9.95 & 1.633 & 0.365 \\
\hline Phosphorus (mg/dl) & 8.08 & 7.80 & 8.17 & 7.95 & 0.668 & 0.321 \\
\hline GOT (IU/L) & 97.00 & 97.25 & 97.33 & 84.00 & 6.356 & 0.497 \\
\hline GPT (IU/L) & 20.25 & 18.13 & 19.17 & 19.75 & 3.827 & 0.542 \\
\hline GGT (mg/dl) & 80.88 & 57.50 & 59.00 & 40.13 & 4.372 & 0.069 \\
\hline
\end{tabular}

BUN blood urea nitrogen, NEFA non-esterified fatty acid, GOT glutamic oxaloacetic transaminase, GPT glutamic-pyruvic transaminase, GGT, gamma-glutamyl transpeptidase

a80C90: weaning at 80 days of age and castration at 90 days of age; W80C180: weaning at 80 days of age and castration at 180 days of age; W130C90: weaning at 130 days of age and castration at 90 days of age; W130C180: weaning at 130 days of age and castration at 180 days of age 
Table 6 Effects of weaning and castration ages on carcass characteristics of Hanwoo steers

\begin{tabular}{|c|c|c|c|c|c|}
\hline \multirow[t]{2}{*}{ Item } & \multicolumn{4}{|l|}{ Treatment $^{a}$} & \multirow[t]{2}{*}{$P$-value } \\
\hline & W80C90 & W80C180 & W130C90 & W130C180 & \\
\hline \multicolumn{6}{|l|}{ Yield traits $^{b}$} \\
\hline Carcass weight (kg) & $446.33 \pm 39.09$ & $470.11 \pm 43.4$ & $464.82 \pm 40.24$ & $468.58 \pm 51.28$ & 0.547 \\
\hline Back fat thickness (mm) & $12.08 \pm 3.15$ & $13.44 \pm 4.36$ & $14.36 \pm 3.96$ & $11.50 \pm 3.61$ & 0.270 \\
\hline Rib eye area $\left(\mathrm{cm}^{2}\right)$ & $93.42 \pm 11.8$ & $94.33 \pm 6.06$ & $101.45 \pm 10.43$ & $97.00 \pm 9.84$ & 0.246 \\
\hline Yield index & $65.39 \pm 1.87$ & $63.99 \pm 3.09$ & $64.47 \pm 3.56$ & $65.59 \pm 3.32$ & 0.579 \\
\hline Yield grade score ${ }^{c}$ & $2.00 \pm 0.60$ & $1.67 \pm 0.71$ & $2.00 \pm 0.77$ & $2.08 \pm 0.67$ & 0.558 \\
\hline \multicolumn{6}{|l|}{ Quality traits $^{\mathrm{d}}$} \\
\hline Marbling score & $6.58 \pm 1.51$ & $6.78 \pm 1.30$ & $7.36 \pm 1.03$ & $6.33 \pm 1.50$ & 0.327 \\
\hline Meat color & $4.92 \pm 0.67$ & $4.78 \pm 0.67$ & $4.91 \pm 0.3$ & $4.75 \pm 0.62$ & 0.861 \\
\hline Fat color & $2.50 \pm 0.52$ & $2.43 \pm 0.50$ & $2.86 \pm 0.49$ & $2.75 \pm 0.45$ & 0.086 \\
\hline Texture & $1.17 \pm 0.39$ & $1.00 \pm 0.00$ & $1.00 \pm 0.00$ & $1.08 \pm 0.29$ & 0.363 \\
\hline Quality grade score ${ }^{e}$ & $4.08 \pm 0.79$ & $4.22 \pm 0.67$ & $4.36 \pm 0.50$ & $4.08 \pm 0.67$ & 0.716 \\
\hline
\end{tabular}

Means \pm standard deviation

a W80C90: weaning at 80 days of age and castration at 90 days of age; W80C180: weaning at 80 days of age and castration at 180 days of age; W130C90: weaning at 130 days of age and castration at 90 days of age; W130C180: weaning at 130 days of age and castration at 180 days of age

${ }^{\mathrm{b}}$ Area was measured from longissmus muscle taken at 13th rib and back fat thickness was also measured at 13th rib; Yield index was calculated using the following equation: $68.184-(0.625 \times$ back fat thickness $(\mathrm{mm}))+\left(0.130 \times\right.$ rib eye area $\left.\left(\mathrm{cm}^{2}\right)\right)-(0.024 \times$ dressed weight amount $(\mathrm{kg}))$; Carcass yield grades from C (low yield) to $A$ (high yield)

${ }^{\mathrm{C}} \mathrm{A}$ grade $=3, \mathrm{~B}$ grade $=2, \mathrm{C}$ grade $=1$

${ }^{d}$ Grading ranges are 1 to 9 for marbling score with higher numbers for better quality $(1=$ devoid, $9=$ abundant $)$; meat color $(1=$ bright red, $7=$ dark red); fat color ( 1 = creamy white, $7=$ yellowish); texture $\left(1=\right.$ soft, $3=$ firm); quality grades from 3 (low quality) to $1^{++}$(very high quality)

${ }^{e} 1^{++}$grade $=5,1^{+}$grade $=4,1$ grade $=3,2$ grade $=2,3$ grade $=1$

respectively (Table 7). The marbling score, meat color, fat color, texture, and meat quality score were similar between the treatment groups.

The carcass weight tended to be higher in C180 $(469.24 \mathrm{~kg})$ than that of C90 $(455.17 \mathrm{~kg})$; however, there was no statistically significant difference (Table 8). Although there was no statistically significant difference, the back fat thickness (13.17 vs. $12.33 \mathrm{~mm}$ ) and rib eye area $\left(97.26\right.$ vs. $95.86 \mathrm{~cm}^{2}$ ) was higher in C90 than that of C180, respectively. The marbling score (6.96 vs. 6.52) and meat quality score (4.22 vs. 4.14) was higher in C90 than that in C180, respectively; however, there was no statistically significant difference.

In the present study, there were small effects of weaning and castration ages on meat quantity and yield traits of Hanwoo steers. This result was probably due to the influence of calf management, feeding methods, and castration age. First, there was no difference in feed intake until 3 months of age as the amount of milk suckling was limited to two times per day from 1 month after birth. Second, there was no difference in the supply of nutrients (energy, protein, and so on) because feed intake (Tables 2, 3, and 4) was similar between the treatment groups due to restricted feeding of concentrates and fixed feeding of rice straw regardless of the treatment groups. Finally, the level of stress caused by castration was similar because calves were castrated before puberty, regardless of the treatment groups. As a result, it is considered that carcass grades were similar as there was no difference in the nutrient utilization efficiency.

In general, early castration has been known to be disadvantageous to carcass weight [18], yet advantageous to marbling score $[5,9,13]$. Although there was no statistically significant difference, results of the present study showed a decrease in carcass weight and increase in marbling with early castration. These results are similar to previous studies. However, the weaning age was considered together with the castration age in the present study, which is different to previous studies. Although there was no positive effect on carcass quality as in previous studies $[19,22]$, there was no negative effect of the early weaning on the carcass grade of Hanwoo steers and the reproduction efficiency of mother cows. Therefore, considering these points, early weaning is expected to have a positive influence on calves and mother cows.

Although the data are not presented in the present study, ultrasound results at 26 months of age showed smaller rib eye areas owing to the early weaning but higher rib eye areas and marbling due to the early castration. At 28 months of age, the marbling score by ultrasound increased owing to the early weaning and castration. Considering these ultrasound results, when the slaughter age is adjusted from 31 months to 28-29 months of age, the early weaning and castration is favorable to the rib eye area and marbling score except for carcass weight. 
Table 7 Effects of weaning age on carcass characteristics of Hanwoo steers

\begin{tabular}{|c|c|c|c|c|}
\hline \multirow[t]{2}{*}{ Item } & \multicolumn{2}{|l|}{ Weaning age $\mathrm{e}^{\mathrm{a}}$} & \multirow[t]{2}{*}{ SE } & \multirow[t]{2}{*}{$p$-value } \\
\hline & W80 & W130 & & \\
\hline \multicolumn{5}{|l|}{ Yield traits $^{b}$} \\
\hline Carcass weight (kg) & $456.52 \pm 41.7$ & $466.78 \pm 45.33$ & 43.639 & 0.440 \\
\hline Back fat thickness (mm) & $12.67 \pm 3.68$ & $12.87 \pm 3.97$ & 3.834 & 0.862 \\
\hline Rib eye area $\left(\mathrm{cm}^{2}\right)$ & $93.81 \pm 9.57$ & $99.13 \pm 10.15$ & 9.880 & 0.082 \\
\hline Yield index & $64.79 \pm 2.50$ & $65.05 \pm 3.40$ & 3.007 & 0.774 \\
\hline Yield grade score ${ }^{c}$ & $1.86 \pm 0.65$ & $2.04 \pm 0.71$ & 0.682 & 0.370 \\
\hline \multicolumn{5}{|l|}{ Quality traits $^{\mathrm{d}}$} \\
\hline Marbling score & $6.67 \pm 1.39$ & $6.83 \pm 1.37$ & 1.380 & 0.704 \\
\hline Meat color & $4.86 \pm 0.65$ & $4.83 \pm 0.49$ & 0.575 & 0.859 \\
\hline Fat color & $2.53 \pm 0.51$ & $2.77 \pm 0.34$ & 0.430 & 0.082 \\
\hline Texture & $1.10 \pm 0.30$ & $1.04 \pm 0.21$ & 0.257 & 0.508 \\
\hline Quality grade score ${ }^{e}$ & $4.14 \pm 0.73$ & $4.22 \pm 0.60$ & 0.663 & 0.712 \\
\hline
\end{tabular}

Means \pm standard deviation

a W80C90: weaning at 80 days of age and castration at 90 days of age; W80C180: weaning at 80 days of age and castration at 180 days of age; W130C90: weaning at 130 days of age and castration at 90 days of age; W130C180: weaning at 130 days of age and castration at 180 days of age ${ }^{\mathrm{b}}$ Area was measured from longissmus muscle taken at 13 th rib and back fat thickness was also measured at 13th rib; Yield index was calculated using the following equation: $68.184-(0.625 \times$ back fat thickness $(\mathrm{mm}))+(0.130 \times$ rib eye area $\left.\left(\mathrm{cm}^{2}\right)\right)-(0.024 \times$ dressed weight amount $(\mathrm{kg}))$; Carcass yield grades from $C$ (low yield) to $A$ (high yield)

${ }^{\mathrm{C}} \mathrm{A}$ grade $=3, \mathrm{~B}$ grade $=2, \mathrm{C}$ grade $=1$

${ }^{\mathrm{d}}$ Grading ranges are 1 to 9 for marbling score with higher numbers for better quality ( 1 = devoid, $9=$ abundant); meat color $(1=$ bright red, $7=$ dark red); fat color $(1=$ creamy white, $7=$ yellowish); texture $(1=$ soft, $3=$ firm); quality grades from 3 (low quality) to $1^{++}$(very high quality)

${ }^{\mathrm{e}} 1^{++}$grade $=5,1^{+}$grade $=4,1$ grade $=3,2$ grade $=2,3$ grade $=1$

Therefore, the results of the present study suggest that the weaning and castration ages have a small effect on ADG, feed intake, FCR, blood metabolism, and carcass characteristics of Hanwoo steers. However, it is considered that early castration is advantageous when the slaughter age is shortened with marbling reduction (i.e., meat quality grade) minimized. Furthermore, early weaning is favorable when reproductive efficiency of mother cows is considered.

The present findings indicated that weaning and castration ages resulted in similar growth performance and carcass characteristics without any negative effect on marbling score in Hanwoo steers. Therefore, early weaning and castration is recommended to reduce the age of slaughter considering meat quality of Hanwoo steers and reproductive efficiencies of Hanwoo cows.

\section{Conclusion}

For the entire experimental period, weaning and castration ages did not significantly affect average daily gain, dry matter intake, and feed conversion ratio of Hanwoo steers. Rib eye area, marbling, and quality grade scores were slightly but not significantly higher in W130C90
Table 8 Effects of castration age on carcass characteristics of Hanwoo steers

\begin{tabular}{|c|c|c|c|c|}
\hline \multirow[t]{2}{*}{ Item } & \multicolumn{2}{|l|}{ Castration age $\mathrm{e}^{\mathrm{a}}$} & \multirow[t]{2}{*}{ SE } & \multirow[t]{2}{*}{$p$-value } \\
\hline & $\mathrm{C} 90$ & C180 & & \\
\hline \multicolumn{5}{|l|}{ Yield traits ${ }^{\mathrm{b}}$} \\
\hline Carcass weight (kg) & $455.17 \pm 39.86$ & $469.24 \pm 46.91$ & 43.361 & 0.289 \\
\hline $\begin{array}{l}\text { Back fat thickness } \\
(\mathrm{mm})\end{array}$ & $13.17 \pm 3.66$ & $12.33 \pm 3.97$ & 3.811 & 0.469 \\
\hline Rib eye area $\left(\mathrm{cm}^{2}\right)$ & $97.26 \pm 11.66$ & $95.86 \pm 8.36$ & 10.223 & 0.652 \\
\hline Yield index & $64.95 \pm 2.78$ & $64.90 \pm 3.24$ & 3.010 & 0.960 \\
\hline Yield grade score ${ }^{c}$ & $2.00 \pm 0.67$ & $1.90 \pm 0.70$ & 0.687 & 0.648 \\
\hline \multicolumn{5}{|l|}{ Quality traits $^{\mathrm{d}}$} \\
\hline Marbling score & $6.96 \pm 1.33$ & $6.52 \pm 1.40$ & 1.364 & 0.299 \\
\hline Meat color & $4.91 \pm 0.51$ & $4.76 \pm 0.62$ & 0.570 & 0.385 \\
\hline Fat color & $2.74 \pm 0.45$ & $2.57 \pm 0.51$ & 0.478 & 0.251 \\
\hline Texture & $1.09 \pm 0.29$ & $1.05 \pm 0.22$ & 0.257 & 0.615 \\
\hline Quality grade score & $4.22 \pm 0.67$ & $4.14 \pm 0.65$ & 0.663 & 0.712 \\
\hline
\end{tabular}

Means \pm standard deviation

${ }^{2}$ W80C90: weaning at 80 days of age and castration at 90 days of age; W80C 180: weaning at 80 days of age and castration at 180 days of age; W130C90: weaning at 130 days of age and castration at 90 days of age; W130C180: weaning at 130 days of age and castration at 180 days of age ${ }^{\mathrm{b}}$ Area was measured from longissmus muscle taken at 13th rib and back fat thickness was also measured at 13th rib; Yield index was calculated using the following equation: $68.184-(0.625 \times$ back fat thickness $(\mathrm{mm}))+(0.130 \times$ rib eye area $\left.\left(\mathrm{cm}^{2}\right)\right)-(0.024 \times$ dressed weight amount $(\mathrm{kg}))$; Carcass yield grades from $\mathrm{C}$ (low yield) to $\mathrm{A}$ (high yield)

${ }^{\mathrm{C}} \mathrm{A}$ grade $=3, \mathrm{~B}$ grade $=2, \mathrm{C}$ grade $=1$

${ }^{\mathrm{d}}$ Grading ranges are 1 to 9 for marbling score with higher numbers for better quality $(1=$ devoid, $9=$ abundant $) ;$ meat color $(1=$ bright red, $7=$ dark red $)$; fat color $(1=$ creamy white, $7=$ yellowish $)$; texture $(1=$ soft, $3=$ firm $)$; quality grades from 3 (low quality) to $1^{++}$(very high quality)

${ }^{\mathrm{e}} 1^{++}$grade $=5,1^{+}$grade $=4,1$ grade $=3,2$ grade $=2,3$ grade $=1$

than in the other treatment groups. Weaning and castration ages did not affect the overall yield and quality traits of carcass. The present findings indicated that weaning and castration ages resulted in similar growth performance and carcass characteristics without any negative effect on marbling score in Hanwoo steers. Therefore, early weaning and castration is recommended to reduce the age of slaughter considering meat quality of Hanwoo steers and reproductive efficiencies of Hanwoo cows.

\section{Abbreviations}

ADG: Average daily gain; BUN: Blood urea nitrogen; C: Castration;

Ca: Calcium; DCP: Dicalcium phosphate; DMI: Dry matter intake; FCR: Feed conversion ratio; GGT: Gamma-glutamyl transpeptidase; GOT: Glutamic oxaloacetic transaminase; GPT: Glutamic-pyruvic transaminase; Mg: Magnesium; NDF: Neutral detergent fiber; NEFA: Non-esterified fatty acid; P: Phosphorus; TDN: Total digestible nutrients; W: Weaning, YI: Yield index

\section{Acknowledgements}

This research was supported by the "RDA Research Associate Fellowship Program" of the National Institute of Animal Science, Rural Development Administration, Republic of Korea.

\section{Funding}

This research was supported by Nonghyup Feed Co., LTD. 


\section{Availability of data and materials}

Authors approved the data and materials availability.

\section{Authors' contributions}

$H L$ and JSA were mainly carried out this study and drafted the manuscript. MJK, GHS, JYS, JHK, and SMC were participated in the feeding trial and blood sampling, together. JKP and IYK performed the statistical analysis and discussed the results. EGK and JSS were participated in the feeding trial and discussed the results. BKP conceived of the study, and participated in its design and coordination and helped to draft the manuscript. All authors read and approved the final manuscript.

\section{Ethics approval and consent to participate}

Protocols involving the use of experimental animals were conducted in accordance the ethical and scientific guidelines of the Animal Experiment Ethics Committee of Kangwon National University (No: KIACUC-16-0010).

\section{Consent for publication}

Not applicable

\section{Competing interests}

The authors declare that they have no competing interest.

\section{Publisher's Note}

Springer Nature remains neutral with regard to jurisdictional claims in published maps and institutional affiliations.

\section{Author details}

${ }^{1}$ Hanwoo Research Institute, National Institute of Animal Science, RDA, Pyeongchang 25340, South Korea. ${ }^{2}$ College of Animal Life Sciences, Kangwon National University, Chuncheon 24341, South Korea. ${ }^{3}$ Nonghyup Feed Co., LTD, Seoul 05398, South Korea.

\section{Received: 27 September 2018 Accepted: 28 November 2018} Published online: 08 December 2018

\section{References}

1. Association of Official Analytical Chemists - A.O.A.C. Official methods of analysis. 16th ed. Washington, DC: Association of Official Analytical Chemists; 1995.

2. Arthaud VH, Mandingo RW, Koch RM, Kotula AW. Carcass composition, quality and palatability attributes of bulls and steers fed different energy levels and killed at four ages. J Anim Sci. 1977;44:53-64.

3. Arthington JD, Spears JW, Mille DC. The effect of early weaning on feedlot performance and measures of stress in beef calves. J Anim Sci. 2005;83:933-9.

4. Cheong JK, Oh YT, Choi HN, Lee CH, Kim KH, Kim KY, Choy YH, Kim HC, Hwang JM. Effects of geographic locations and year-seasons of birth on ultrasound scanned measures and carcass traits of Hanwoo steers. J Anim Sci Technol. 2012;54:247-53.

5. Cosgrove GP, Knight TW, Lambert MG, Death AF. Effects of post-pubertal castration and diet on growth rate and meat quality of bulls. Proc N Z Soc Anim Prod. 1996;56:390-3.

6. Field RA. Effect of castration on meat quality and quantity. J Anim Sci. 1971; 32:849-58.

7. Fisher AD, Knight TW, Cosgrove GP, Death AF, Anderson CB, Duganzich DM, Matthews LR. Effects of surgical or banding castration on stress responses and behaviour of bulls. Aust Vet J. 2001;79:279-84.

8. Green WW, Buric J. Comparative performance of beef calves weaned at 90 and 180 days of age. J Anim Sci. 1953;12:561-72.

9. Jago JG, Matthews LR, Bass JJ. Knight TW. A comparison of two methods of castration of post-pubertal beef cattle and their effect on behavior, growth and ultimate pH. Proc N Z Soc Anim Prod. 1996;56:395-7.

10. Jung KK, Kim DG, Sung KK, Choi CB, Kim SG, Kim DY, Choi BJ, Yun YT. Effect of castration on the carcass grade of Hanwoo and Holstein. J Anim Sci Technol. 1996;38:249-60.

11. Kim WY, Lee SH, Hwang JH, Kim SK, Lee SS, Yeo JM. Effects of concentrate feeding on rumen papillae development in Hanwoo calves before weaning. J Anim Sci Technol. 2012;54:355-9.

12. King $\mathrm{BD}$, Cohen $\mathrm{RDH}$, Guenther $\mathrm{CL}$, Janzen $\mathrm{ED}$. The effect of age and method of castration on plasma cortisol in beef calves. Can J Anim Sci. 1991;71:257-63.
13. Knight TW, Cosgrove GP, Death AF, Anderson CB. Effect of interval from castration of bulls to slaughter on carcass characteristics and meat quality. New Zeal J Agr Res. 1999;42:269-77.

14. Ministry of Agriculture, Food and Rural Affairs (MAFRA). Grade rule for cattle carcass in Korea. Korea Ministry of Government Legislation. 2017. http:// www.law.go.kr/main.htm. Accessed 30 Nov 2017.

15. Kwon EG, Cho YM, Park BK, Choi CW, Kim YG, Paek BH. Effect of calving season on growth performance, feed intake and disease occurrence of Hanwoo calves. J Anim Sci Technol. 2007:49:59-66.

16. Lee CW, Lee CM, Lee SJ, Song YH, Lee JK, Kim JB. Effects of raising farm on genetic evaluation for carcass traits in Hanwoo cows. J Anim Sci Technol. 2011;53:325-32.

17. Lusby $K$, Wettemann R. Effects of early weaning calves from first calf heifers on calf and heifer performance. Anim Sci Res. 1980;107:55-8.

18. Mach N, Bach A, Realini CE, Fonti Furnols M, Velarde A, Devant M. Burdizzo pre-pubertal castration effects on performance, behavior, carcass characteristics, and meat quality of Holstein bulls fed high-concentrate diets. Meat Sci. 2009;81:329-34

19. Makarechian MH, Kubisch M, Price MA. Effects of date of weaning on subsequent performance of beef cows and their female calves. Can J Anim Sci. 1988;68:1035-40

20. Mark DR, Schroeder TC, Jones R. Identifying economic risk in cattle feeding. J Agribus. 2000;18:331-44.

21. Meyer DL, Kerley MS, Walker EL, Keisler DH, Pierce VL, Schmidt TB, Stahl CA, Linville ML, Berg EP. Growth rate, body composition, and meat tenderness in early vs traditionally weaned beef calves. J Anim Sci. 2005:83:2752-61.

22. Myers SE, Faulkner DB, Ireland FA, Parrett DF. Comparison of three weaning ages on cow-calf performance and steer carcass traits. J Anim Sci. 1999;77: 323-9.

23. National Institute of Animal Science. Korean feeding standard for Hanwoo. 2017. pp. 44-50

24. Park BH, Park YI. Adjustment of weaning weight to an age-constant basis in Hanwoo. J Anim Sci Technol. 2000:42:745-50.

25. Peterson GA, Turner TB, Irvin KM, Davis ME, Newland HW, Harvey WR. Cow and calf performance and economic considerations of early weaning of fallborn beef calves. J Anim Sci. 1987;64:15-22.

26. Purchas RW. An assessment of the role of $\mathrm{pH}$ differences in determining the relative tenderness of meat from bulls and steers. Meat Sci. 1990;27:129-40.

27. Pyatt NA, Berger LL, Faulkner DB, Walker PM, Rodriguez-Zas SL. Factors affecting carcass values and profitability in early-weaned Simmental steers: II. Days on feed endpoints and sorting strategies. J Anim Sci. 2005;83:2926-37.

28. Roh SH, Kim CY, Won YS, Park CJ, Lee SS, Lee JG. Studies on genetic parameter estimation and sire selection to ultrasound measurement traits of Hanwoo. J Anim Sci Technol. 2010;52:1-8.

29. SAS. SAS/STAT Software for PC. Release 9.1.3 version Edition. Cary, NC: SAS instititute; 1999

30. Seideman SC, Cross HR, Oltjen RR, Schanbacher BD. Utilization of the intact male for red meat production: a review. J Anim Sci. 1982:55:826-40.

31. Short RE, Grings EE, MacNeil MD, Heitschrnidt RK, Williams CB, Bennett GL. Effects of sire growth potential, growing-finishing strategy, and time on performance, composition and efficiency of steers. J Anim Sci. 1999;77: 2406-17.

32. Story CE, Rasby RJ, Clark RT, Milton $C T$. Age of calf at weaning of springcalving beef cows and the effect on cow and calf performance and production economics. J Anim Sci. 2000;78:1403-13.

33. Van Soest PJ, Roberts JB, Lewis BA. Methods for dietary fiber, neutral detergent fiber, and non-starch polysaccharides in relation to animal nutrition. J Dairy Sci. 1991;74:3583-97.

34. Vanderwert W, Berger LL, McKeith FK, Baker AM, Gonyou HW, Bechtel PJ. Influence of zeranol implants on growth, behavior and carcass traits in Angus and Limousin bulls and steers. J Anim Sci. 1985;61:310-9.

35. Worrell MA, Clanton DC, Calkins CR. Effect of weight at castration on steer performance in the feedlot. J Anim Sci. 1987:64:343-7. 